\title{
Dual roles of the retinoblastoma protein in cell cycle regulation and neuron differentiation
}

\author{
Eva Y.-H.P. Lee, ${ }^{1,4}$ Nanpin Hu, ${ }^{1}$ Shyng-Shiou F. Yuan, ${ }^{1}$ Laura A. Cox ${ }^{1}$ Alan Bradley, ${ }^{2}$ \\ Wen-Hwa Lee, ${ }^{1}$ and Karl Herrup ${ }^{3}$ \\ ${ }^{1}$ Center for Molecular Medicine/Institute of Biotechnology, The University of Texas Health Science Center at San Antonio, \\ San Antonio, Texas 78245 USA; ${ }^{2}$ Institute for Molecular Genetics and Howard Hughes Medical Institute, Baylor College \\ of Medicine, Houston, Texas 77030 USA; $^{3}$ Alzheimer Research Lab, Case Western Reserve Medical School, \\ Cleveland, Ohio 44106 USA
}

To assess the functions of the retinoblastoma protein (RB) during normal development, we have analyzed mouse embryos that lack a functional copy of the retinoblastoma gene (genotype: $R b-1^{\Delta 20} / R b-1^{\Delta 20}$ ). Our findings demonstrate that RB plays an important role in the regulation of the neuronal cell cycle. In mutant embryos, dividing cells are found well outside of the normal neurogenic regions in both the central and peripheral nervous systems. In addition to abnormal cell cycle regulation, however, the mutant embryos show two less expected phenotypes. First, many of the ectopically dividing cells die by apoptosis shortly after their entrance into $S$ phase. In sensory ganglia, most nerve cells die by this process, beginning at about the same time as normal target-related neuronal death. Second, although the expression of certain differentiation markers such as N-CAM and Brn-3.0 appears to be near normal, nerve cells, especially in sensory ganglia, do not mature properly. Their morphology is stunted and expression of neuronal $\beta I I$ tubulin is greatly reduced. Preferential reduction in the expression of TrkA, TrkB, and the low-affinity neurotrophin receptor $\mathbf{p} 75^{\mathrm{LNGFR}}$ may be relevant to neuronal cell death and lack of neuronal differentiation seen in the mutant embryos. Primary cultures of dorsal root and trigeminal ganglion cells from later stage mutant embryos reveal a decrease in neuronal cell survival and in neurite outgrowth even in the presence of the appropriate neurotrophins. Taken together, these results suggest that the $\mathrm{p} 1 \mathbf{1 0}^{\mathrm{RB}}$ protein not only regulates progression through the cell cycle but is also important for cell survival and differentiation.

[Key Words: Retinoblastoma gene; cell cycle control; apoptosis; neuronal differentiation]

Received May 25, 1994; revised version accepted July 18, 1994

The differentiation of a nerve cell is a process that begins early in embryonic development and continues through subsequent cell divisions, migrations, and maturations. It culminates in the acquisition of the form and function that define each specific adult cell type. One important characteristic that applies to all mature nerve cells is that they never divide. Most central nervous system (CNS) neurons undergo their final cell division during embryogenesis and remain locked in a $G_{0}$ cell cycle state for the remainder of the life of the organism. This cell cycle arrest is one of the earliest events in the neuronal maturation process, although the expression of pattern formation genes (e.g., Buolfone et al. 1993) as well as certain differentiation markers (Ma et al. 1992) can precede it (see also Rothman et al. 1980).

A complete description of the cellular and molecular mechanisms that regulate the neuronal differentiation

${ }^{4}$ Corresponding author. process, including cell cycle arrest, is currently far from complete. One important constituent of the process, however, is the tumor suppressor gene retinoblastoma. The retinoblastoma gene product, $\mathrm{pl} 10^{\mathrm{RB}}$, is a nuclear protein that is expressed throughout the developing organism (Lee et al. 1987; Bernards et al. 1989; Szekely et al. 1992). At least five different phosphorylated forms of the protein are found in cycling cells (Shew et al. 1989; Ludlow et al. 1990), and the relative balance among these forms varies during the four phases of the cell cycle (Buchkovich et al. 1989; Chen et al. 1989; DeCaprio et al. 1989, 1992). Hypophosphorylated retinoblastoma (RB) protein predominates in $G_{1}$. As cells enter $S$ phase, phosphorylated forms become more abundant, and these forms persist through $S, G_{2}$, and $M$ phases. Multiple serine and threonine residues are phosphorylated (Lin et al. 1991; Hu et al. 1992), and sequential phosphorylation of specific sites has been reported (DeCaprio et al. 1992). As cells enter anaphase, RB dephosphorylation begins and continues, stepwise, until $G_{1}$ when $R B$ is once again 
Dual roles of RB protein during development

hypophosphorylated (Ludlow et al. 1993). RB phosphorylation not only correlates with the phase of the cell cycle, but several studies have suggested that RB is part of the mechanism that regulates the cell cycle. Cells into which $\mathrm{RB}$ has been introduced by retroviral infection (Huang et al. 1988), microinjection (Goodrich et al. 1991), or transfection (Qin et al. 1992) show a reduced growth rate attributable to inhibition of cell cycle progression from $G_{1}$ to $S$ phase. The mechanism by which unphosphorylated RB inhibits this progression is likely to involve the RB-associated transcription factor E2F-1 (Helin et al. 1992; Kaelin et al. 1992; Shan et al. 1992). Finally, in addition to a major role in the $\mathrm{G}_{1}$-to-S transition, RB may act at other stages in the cell cycle. For example, it has been shown recently that RB may result in $G_{2}$ arrest if it is overexpressed during $S$ phase of the cell cycle (Karantza et al. 1993).

Mice with null alleles at the $R b-1$ locus have been generated independently by three laboratories (Clarke et al. 1992; Jacks et al. 1992; E.Y.-H.P. Lee et al. 1992). Lee et al. (1992) mutated the RB gene at exon 20 resulting in a carboxy-terminal truncated protein. This mutation (designated $R b-1^{\Delta 2 O}$ ) destroys the regions in the RB protein that are required for binding to many cellular proteins, including E2F-1. Heterozygous, $R b-1^{\Delta 20} /+$, mice develop pituitary tumors of intermediate lobe origin with nearly $100 \%$ penetrance (Hu et al. 1994). Analysis of DNA from the cells of these tumors inevitably reveals loss of the wild-type $R b-1$ allele (Jacks et al. 1992; Hu et al. 1994). This is consistent with the behavior of the gene in human retinoblastoma tumors and with the proposed role of $R b-1$ as a tumor suppressor gene. Homozygous $R b-1^{\Delta 20} / R b-1^{\Delta 20}$, mutant embryos die between days 12.5 and 16.0 of gestation (E12.5-E16). Although most organs appear to develop properly, there are major defects in the nervous and hematopoietic systems. One of these defects is the presence of ectopic mitotic figures in the developing nervous system located at some distance from the normal neurogenic regions. Such cells are not observed in normal mice and their presence in the RBdeficient mutants is in keeping with the proposed role of $\mathrm{RB}$ as a cell cycle regulator (E.Y.-H.P. Lee et al. 1992). Some of the phenotypes of homozygous embryos, however, are somewhat paradoxical. For example, massive amounts of cell death are found in the same regions as the dividing cells. Dying cells can be found in all regions of the CNS and peripheral nervous system (PNS), but they are especially prevalent in hindbrain, spinal cord, and sensory ganglia.

Our current understanding of the $\mathrm{p} 110^{\mathrm{RB}}$ protein function offers no means of explaining the phenotype of the $R b-1^{\Delta 20} / R b-1^{\Delta 20}$ embryos. In this study we address the function of $R B$ in both the regulation of the cell cycle and in differentiation. We report that cells in the nervous system of the mutant embryos fail to become postmitotic and die by apoptosis. In addition, the levels of expression of several early neuronal differentiation markers are reduced, leading to the suggestion that $\mathrm{p} 110^{\mathrm{RB}}$ serves a complex developmental function that transcends a single role in cell cycle regulation.

\section{Results}

Post-translational modification of the $R B$ protein during CNS development

Abnormalities in the CNS of $R b-1^{\Delta 20} / R b-1^{\Delta 20}$ embryos appear as early as embryonic day 10 (E10). To assess the correlation of these abnormalities with the activity of RB protein during development, we analyzed $\mathrm{RB}$ expression in the CNS from embryos of different ages. RB protein is detectable by Western blot at E9.5 (Fig. 1); significantly, at this early age, most of the protein is found as one of the phosphorylated isoforms. At E10.5, the level of RB has increased, and the fraction of the protein that is in the unphosphorylated state is substantially greater. This trend continues through E12.5, and by E14.5 the phosphorylated forms of RB are nearly undetectable. This developmental shift in RB can be contrasted with the G $\beta$ like protein (Shan et al. 1992) and the RB-associated protein RbAp48 (Qian et al. 1993). Western blot analysis of these two proteins reveals that their levels remain nearly constant during the same developmental time period. Appearance of unphosphorylated RB protein correlates with the times at which most neurons in the midbrain and hindbrain have left the cell cycle (Taber-Pierce 1973), consistent with the role of unphosphorylated RB in inhibiting cell cycle progression from $G_{1}$ to $S$ phase (Goodrich et al. 1991). Significantly, the timing of the appearance of the nervous system defects seen in the $R b-1^{\Delta 20} / R b-1^{\Delta 20}$ embryos correlates with the increasing predominance of unphosphorylated forms of RB.

\section{Cells in RB-deficient embryos continue to transit the cell cycle}

Because $\mathrm{RB}$ protein inhibits cell cycle progression from $G_{1}$ to $S$, we used a fluorescence-activated cell sorter

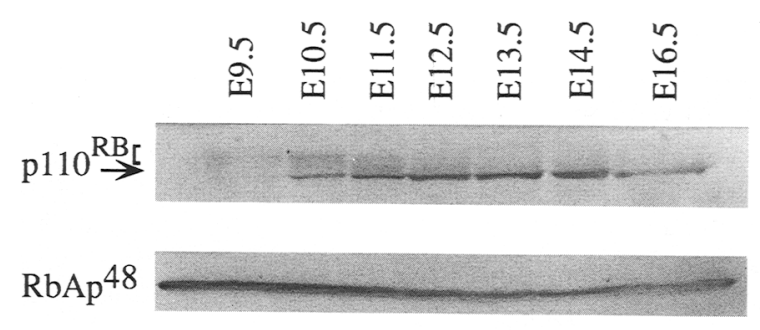

Gß-like

Figure 1. RB protein expression during embryonic development. About $600 \mu \mathrm{g}$ of protein extract from E9.5, E10.5, and E11.5 embryonic heads, and E12.5, E13.5, E14.5, and E16.5 embryonic brains were separated on a $6-15 \%$ gradient gel, and areas containing proteins of interest were analyzed by Western blotting. RbAp48, an RB-associated protein, and G $\beta$-like protein served as controls for the quantities of protein loaded. The former was revealed with a monoclonal antibody; the latter was revealed with a polyclonal antiserum. The bracket indicates phosphorylated RB protein. 
(FACS) analysis to study cell cycle distribution in the RB-deficient mutants. Cells were harvested from the hindbrain region of mutant and control embryos at E13.5. Cells from wild-type embryos had a fluorescence pattern that was consistent with $4 \%$ of the population being in S phase (Fig. 2a). In contrast, cells from the mutant had double this number (Fig. 2b). Similar results were found when cells were harvested from the cervical spinal cord (Figs. 2c,d).

To pursue these observations in situ, we used bromodeoxyuridine (BrdU) to label dividing cells. Following injection into a pregnant female, embryonic cells that are in $\mathrm{S}$ phase will take up BrdU from the circulation and incorporate it into DNA. A single injection delivers a pulse of S-phase label to the developing fetuses. The cells that were synthesizing DNA during this pulse can then be revealed by immunocytochemistry using antibodies against BrdU (Nowakowski et al. 1989). In normal embryos, the ventricular zone of the CNS is a highly organized germinative center. The distance of a cell's nucleus from the lumen of the neural tube is essentially proportional to its distance from $M$ phase of the cell cycle. Thus, mitotic figures are only found at the lumenal surface. As cells enter $G_{1}$, their nucleus ascends and cells enter $S$ phase at the outermost regions of the ventricular zone. During $G_{2}$, the nucleus descends to the lumen to enter $M$ phase once more at the surface of the lumen. In keeping with this pattern, if E12.5 embryos are sacrificed $1 \mathrm{hr}$ after injection, BrdU-positive nuclei are found only in the synthetic region of the ventricular zone of the neural tube (Fig. 3a) and in cells in the sensory ganglia. If sacrifice and fixation of the embryos are delayed until $3 \mathrm{hr}$ after BrdU injection, labeled nuclei in the wild-type embryos are now found at the lumenal surface (Fig. 3c). In E12.5 $R b-1^{\Delta 20} / R b-1^{\Delta 20}$ mutants, proliferative cells are present in the synthetic regions of the ventricular zone, but many labeled nuclei are also found in regions normally reserved for migrating and maturing neurons (Fig. 3b). Descent of labeled nuclei is seen in mutant embryos if survival time after BrdU injection is lengthened (Fig. 3d). Even though the cells in the mutant ventricular zone appear to cycle properly, however, proliferative cells are found throughout the CNS in zones where normally only postmitotic cells reside.

By E14.5, cell proliferation is nearly complete and the ventricular zone contains only a few cycling cells (most likely non-neuronal) that are labeled with BrdU (Fig. 3e). The spinal ganglia still contain labeled cells, but their numbers have decreased. In contrast, in mutant embryos, many cells continue to enter the cell cycle throughout the CNS (Fig. 3f). In the PNS, the number of labeled cells in mutant embryos far exceeds that found in the wild type (cf. Fig. 3, e and f). The BrdU injections illustrate that the cells of RB-deficient embryos enter $\mathrm{S}$ phase even in zones of the neural tube that are normally reserved for postmitotic cells. Furthermore, proliferation of the cells continues, nearly unabated, until the ages at which the mutant embryos die. In contrast to these findings in the nervous system, little difference is found in the patterns of cell division in other tissues. For example, in the embryonic tongue where muscle fibers and dividing myoblasts can be identified, the patterns of BrdU incorporation in mutant and wild-type embryos are nearly indistinguishable (Fig. $3 \mathrm{~g}, \mathrm{~h}$ ). The results suggest

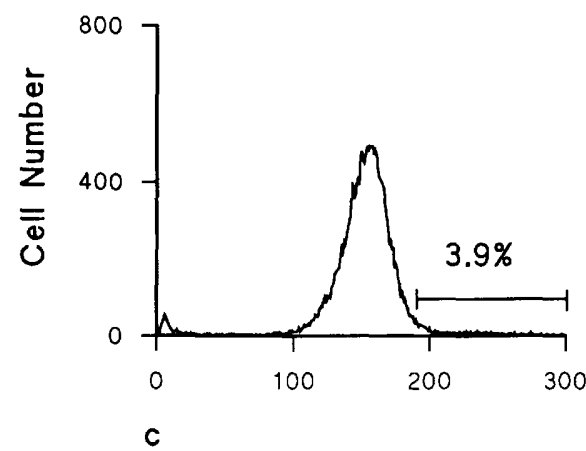

है phase. (a) Hindbrain of wild-type embryos; (b) hindbrain of $R b-1^{\Delta 20} / R b-1^{\Delta 20}$ embryos; (c) cervical spinal cord of wild-type embryos; $(d)$ cervical spinal cord of $R b-1^{\Delta 20}$, $R b-1^{\Delta 2 o}$. a

b
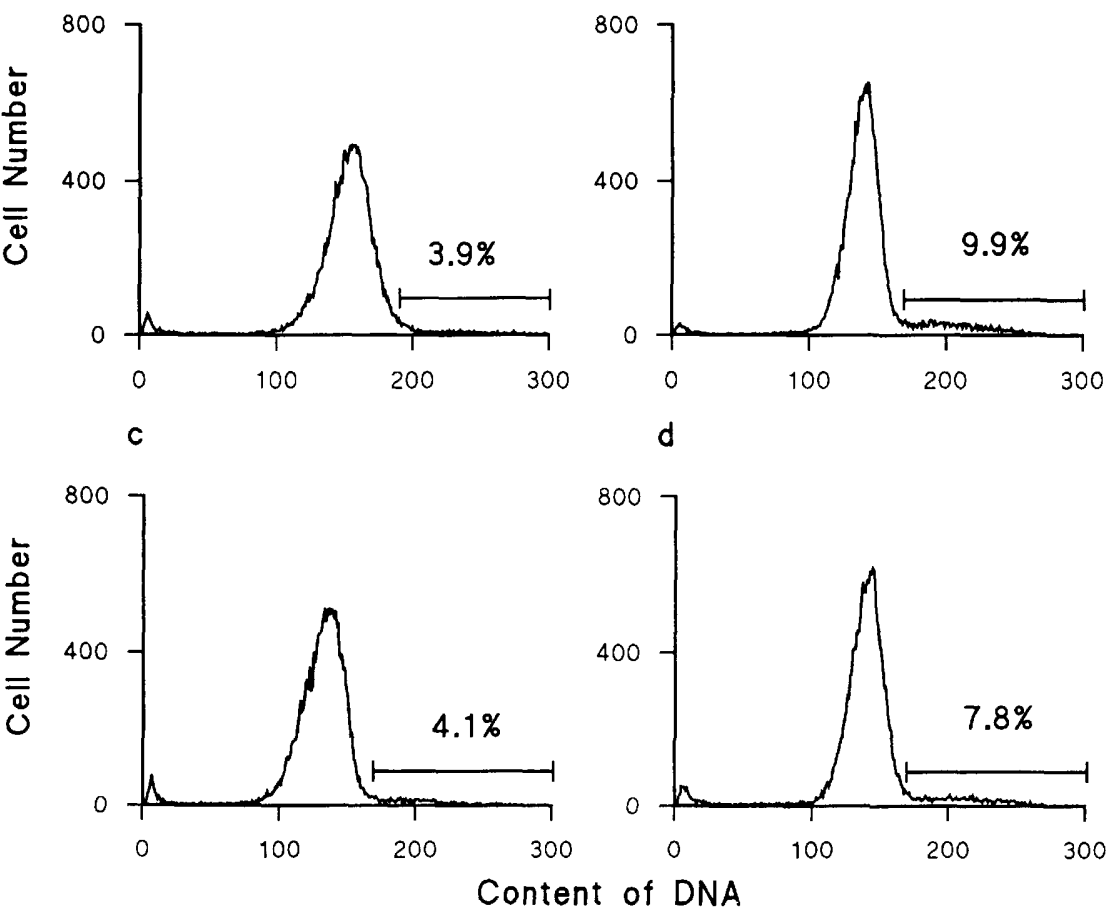


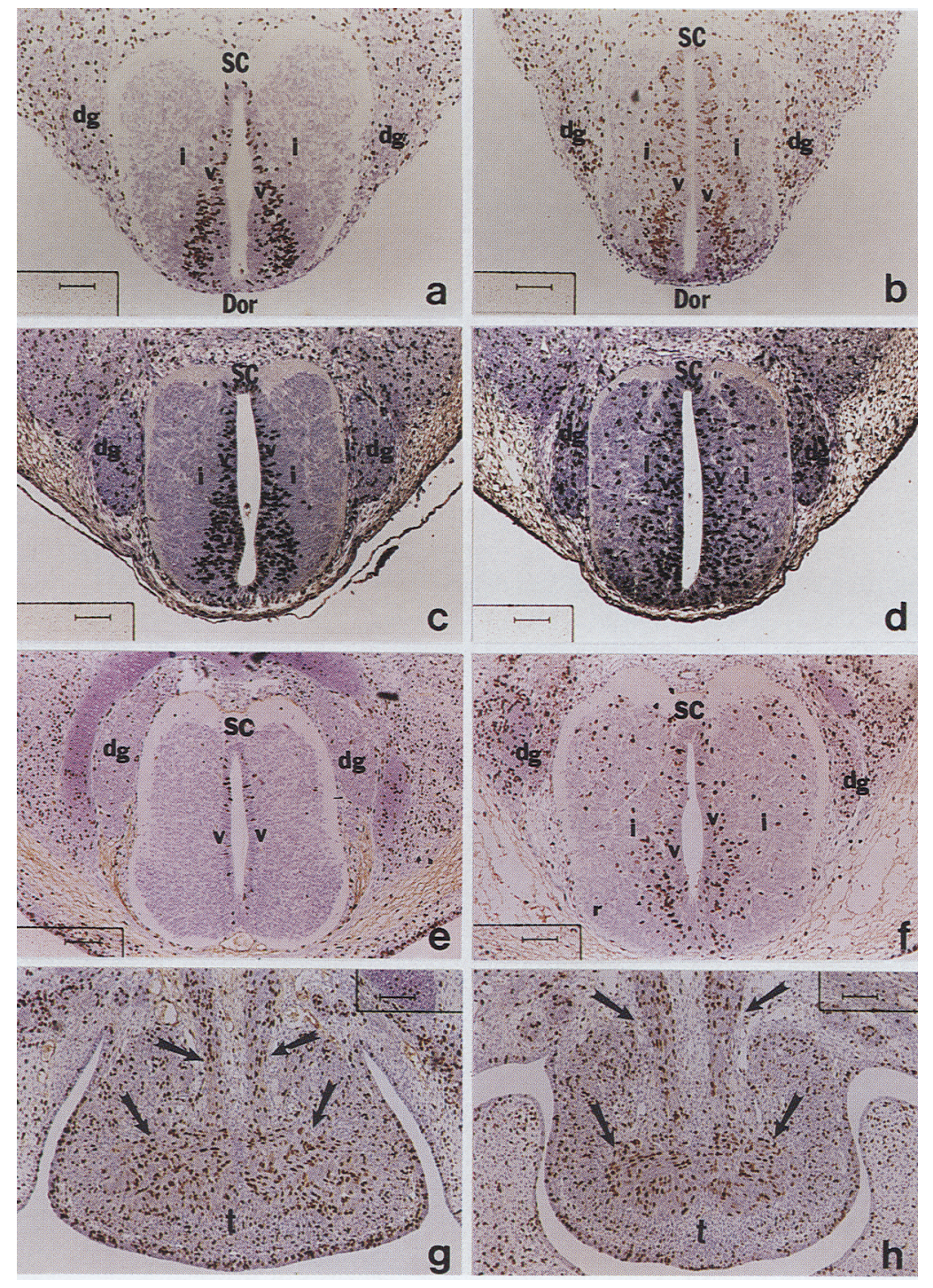

Figure 3. DNA synthesis in the spinal cord and dorsal root ganglia of wild-type and $R b-1^{\Delta 20} / R b$ $1^{\Delta 20}$ embryos. $(a-f)$ Transverse sections of the embryonic spinal cord and associated ganglia were immunostained with an anti-BrdU monoclonal antibody. (Left) Wild-type embryos; (right) mutant embryos. $(a, b)$ E12.5 embryos were sacrificed $1 \mathrm{hr}$ after BrdU injection. $(c, d)$ El3.5 embryos were sacrificed $3 \mathrm{hr}$ after BrdU injection. $(e, f) \mathrm{E} 14.5 \mathrm{em}-$ bryos were sacrificed $1 \mathrm{hr}$ after BrdU injection. Note that in mutant embryos cells in the intermediate zone as well as the ventricular zone undergo DNA synthesis. $(g, h)$ Longitudinal sections of the embryonic tongue. E14.5 embryos were sacrificed $l \mathrm{hr}$ after BrdU injection to show the pattern of dividing cells in control $(g)$ and mutant $(h)$ tongue. (dg) Dorsal root ganglion; (i) intermediate zone; (v) ventricular zone; (sc) spinal cord; (t) tongue; (arrow) muscle fibers in tongue; (Dor) dorsal side. Scale bar, $100 \mu \mathrm{m}$. that without RB protein, cell cycle arrest during neurogenesis is incomplete.

\section{Apoptosis in RB-deficient embryos}

Although we observed the spatial correlation of ectopic mitoses and cell death previously (E.Y.-H.P. Lee et al. 1992), there was no direct proof that the dying cells were the ones that had divided recently. The BrdU injection studies allow us to address this question. Following a short pulse of BrdU, immunostained pycnotic remnants can be identified (Fig. 4b, arrows). This cellular debris must be removed soon after the cells enter $S$ phase because the numbers of pycnotic, BrdU-positive cells decrease if the embryos are labeled for $3 \mathrm{hr}$ (Fig. 3; data not shown). Thus, it appears that many of the dead cells are cells that have recently entered the cell cycle and begun to synthesize DNA.

We asked whether the cell death associated with the failure of the $R b-1^{\Delta 20} / R b-1^{\Delta 20}$ cells to exit the cell cycle was apoptotic programmed cell death. Genomic DNA was extracted from E13.5 dorsal root and trigeminal ganglia, where pycnotic cells are most prominent. The DNA was end-labeled using $\left[\alpha-{ }^{32} \mathrm{P}\right] \mathrm{ddATP}$ and separated on an agarose gel (Tilly and Hsueh 1993). The characteristic ladder of DNA fragments, a hallmark of apoptosis, was prominent in mutant and, to a much lesser degree, in wild-type embryos (Fig. 5a). No evidence of fragmentation could be found in DNA from tails of adult mice. This suggests that the cell death seen in the mutant embryonic nervous system is apoptotic in nature.

To confirm this in situ, we applied the TUNEL [terminal deoxynucleotide transferase (TdT)-mediated dUTP-biotin nick end labeling] technique to histological sections of embryonic tissue (Gavrieli et al. 1992). By labeling DNA on sections using terminal deoxynucleotide transferase, any cell undergoing DNA fragmentation will expose numerous "ends" for dUTP-biotin 
Figure 4. Consequences of ectopic mitosis. A higher magnification view of the spinal cord (sc) and dorsal root ganglia (dg) of E14.5 wild-type embryo $(a)$ and mutant embryo $(b)$, following a $1-\mathrm{hr}$ pulse-label of BrdU. Note the condensed and fragmented BrdU-positive nuclei of apoptotic cells in the mutant embryos. Abbreviations as in Fig. 3. Scale bar, $20 \mu \mathrm{m}$.
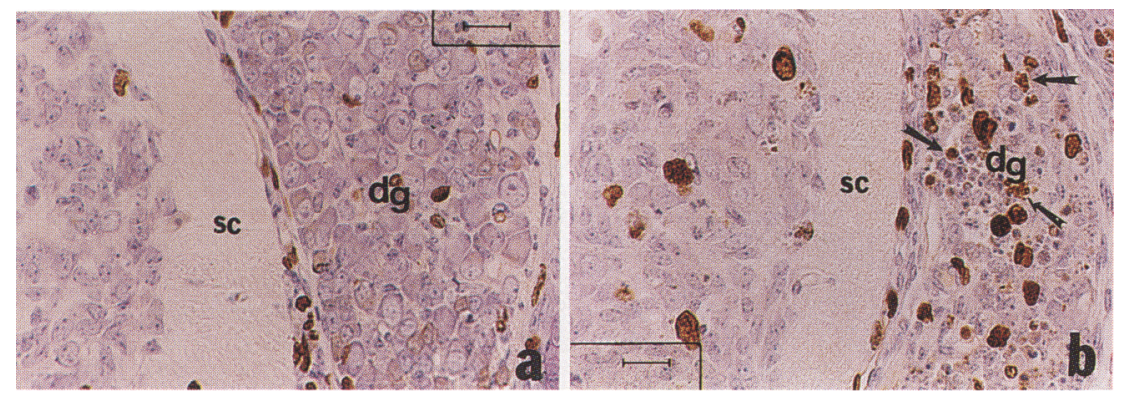

addition. In wild-type embryos, TUNEL staining is observed throughout the nervous system during development. In the PNS of both mutant and wild-type embryos, the first structure that shows positive cells is the trigeminal ganglion. At E11.5, however, a two- to threefold elevation in the density of apoptotic cells is seen in RBdeficient embryos compared with wild type (Fig. 5b,c). Twenty-four hours later, the same phenomenon is repeated in the dorsal root ganglia (Fig. 5d,e). In the spinal cord of the mutant embryos, apoptotic cell clusters are seen in the outer half of the ventricular zone as well as in the more superficial nerve cell regions. The time of appearance and spatial distribution of the apoptotic cells is unique in each region and is highly reproducible from one mutant embryo to the next.

\section{Sensory neurons in RB-deficient embryos undergo incomplete differentiation}

Several morphological observations have prompted us to ask whether RB might function in yet another capacity during neuronal maturation. This issue is well illustrated by the cells of the spinal ganglia. In wild-type embryos, by E14.5, most neurons in the trigeminal ganglion are well differentiated with large nuclei and well developed Nissl substance (Fig. 6a). In contrast, those trigem-

Figure 5. Programmed cell death in the trigeminal and dorsal root ganglia of $R b$. $1^{\Delta 20} / R b-1^{\Delta 20}$ embryos. (a) DNA ladder of fragmented genomic DNA. (Lane 1) Five hundred nanograms of genomic DNA from adult mouse tail. (Lanes 2-4) DNA from E13.5 dorsal root ganglia: (lane 2) wild type; (lane 3 ) heterozygous, and (lane 4) mutant. (b-e) TUNEL staining of apoptotic nuclei. Coronal sections showing dorsal root ganglia from E11.5 $(b, c)$ and E12.5 embryos $\{d, e\rangle$ were processed for the TUNEL technique to identify cells undergoing apoptotic, programmed cell death. $(b, d)$ Wild-type embryo; $(c, e) R b-1^{\Delta 20} / R b$ $1^{420}$ embryo. (dg) Dorsal root ganglia; $(\mathrm{tg})$ trigeminal ganglia; (Dor) dorsal side. Scale bar, $100 \mu \mathrm{m}(b, c)$ and $80 \mu \mathrm{m}(d, e)$.

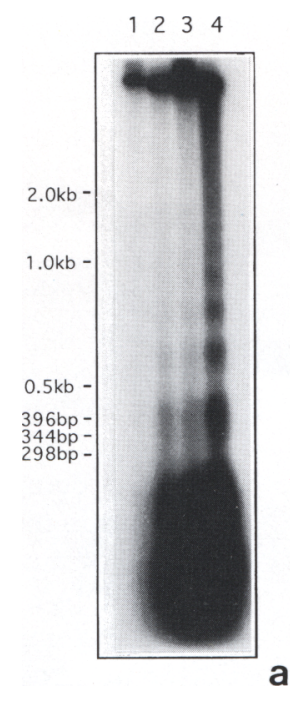

inal ganglion cells that survive in the $R b-1^{\Delta 20} / R b-1^{\Delta 20}$ mutant appear much less differentiated (Fig. 6b). They have smaller cell bodies and scant cytoplasm with little or no dark Nissl substance. The nuclei of even the largest mutant cells are dramatically smaller than their wildtype counterparts, although the nucleoplasm is clear and one or two nucleoli are visible. Similar observations are made in dorsal root ganglia from comparable axial levels at E14.5 (Fig. 4a,b), and in the CNS (data not shown). Curiously, this poor cytological development does not seem to be correlated with problems in axonal outgrowth. Analysis of the cranial and spinal nerves was performed by whole-mount immunostaining of E10.5 and E11.5 embryos using an antibody $(2 \mathrm{H} 3)$ directed against the $155-\mathrm{kD}$ component of neurofilament. The central and peripheral nerves of the trigeminal, petrosal, and nodose ganglia are all formed in the $R b-1^{\Delta 20} / R b-1^{\Delta 2 O}$ mutant (Fig. 7, cf. b with the $+1+$ embryo in a). Thus, neither the absence of RB protein nor the poor cytological state of the ganglion cell bodies prevented proper axonal outgrowth and guidance.

\section{Expression of specific genes in RB-deficient embryos}

These morphological observations led us to examine the expression of several genes known to be active during early nervous system development. Many POU domain

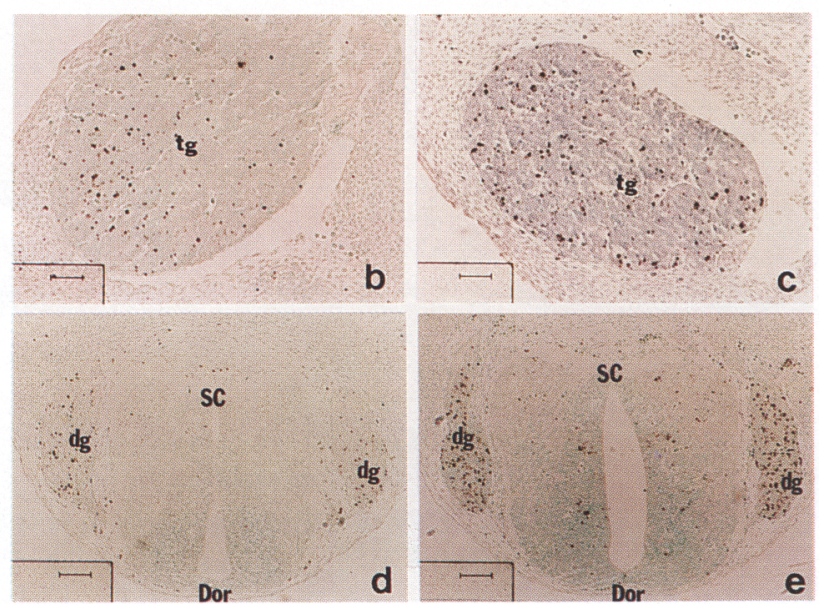

a 

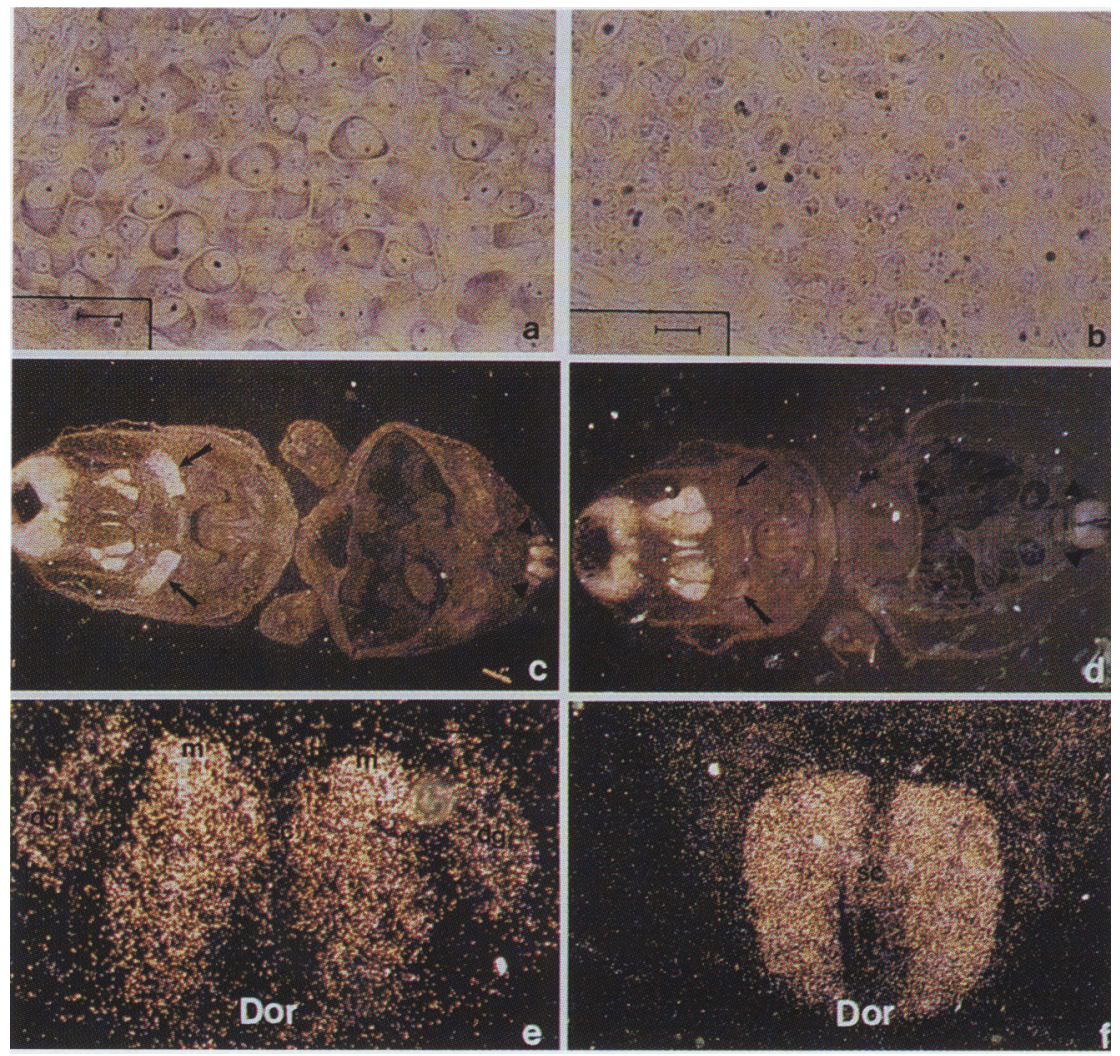

Figure 6. Incomplete differentiation of trigeminal ganglia neurons of $R b-1^{\Delta 20} / R b$ $1^{\Delta 20}$ embryos. $|a, b|$ Trigeminal ganglia in the coronal sections of E14.5 wild-type $(a)$ and mutant $(b)$ embryos. Note the presence of large neuronal nuclei and prominent Nissl substance in wild-type but not mutant embryos. $(c-f)$ Expression of $\beta I I$ tubulin mRNA as detected by in situ hybridization. Coronal sections from E13.5 wildtype $(c, e)$ and mutant $(d, f)$ embryos are shown. (Arrow) trigeminal ganglia; (arrowhead), dorsal root ganglia; $(\mathrm{m})$ Motor horn. Scale bar, $12.5 \mu \mathrm{m}(a, b)$.

genes have been shown to be involved in neuronal differentiation and cell type specification ( $\mathrm{He}$ and Rosenfeld 1991). One member of the POU family, Brn-3.0, is expressed in sensory ganglion starting at E9.5, with peak expression by E12.5 (Gerrero et al. 1993). In situ hybridization using a specific oligonucleotide shows that the expression patterns of Brn-3.0 are similar in mutant (Fig. 7d,f) and wild-type embryos (Fig. 7c,e). Likewise, the expression of message for the neural cell adhesion molecule, NCAM, appears to be unchanged in the mutant (not shown). Thus, in addition to axonal growth, the expression of some developmentally regulated genes is not affected by the $R b-1^{\Delta 20}$ mutation.

As with the morphology, however, many molecular features of neuronal differentiation are either retarded or blocked in the mutant embyros. The BII isoform of tubulin is neuron specific and its expression normally increases dramatically during the early differentiation of most nerve cells. At E11.5 and E13.5, $\beta$ II tubulin is expressed in the wild-type brain and spinal cord, as well as in the trigeminal and dorsal root ganglia (Fig. 6c,e). In the CNS of the mutant embryos, expression of $\beta I I$ tubulin was not obviously different from wild type. In trigeminal and dorsal root ganglia, however, levels of $\beta I I$ tubulin message decreased to nearly background levels (Fig. 6d,f).

The defects in the $R b-1^{\Delta 20} / R b-1^{\Delta 20}$ embryos are found throughout the length of the neuraxis, but they are most dramatic in the neurons of the peripheral ganglia. As these PNS centers are critically dependent on several of the known neurotrophin molecules for survival, we sought to characterize the effects of the $R b-1^{\Delta 20}$ mutation on the expression of several neurotrophic factors and their receptors. The message levels for the growth factors themselves-nerve growth factor (NGF), brainderived neurotrophic factor (BDNF), and neurotrophin-3 (NT-3)-are not altered significantly in mutants (by in situ hybridization, not shown). On the other hand, expression of both the low-affinity (p75 ${ }^{\text {LNGFR) }}$ and highaffinity (TrkA) NGF receptor are greatly reduced in sensory ganglia. At E12.5, p75 ${ }^{\text {LNGFR }}$ can be detected in the ventral horn of the spinal cord of both mutant (Fig. $8 \mathrm{~b}, \mathrm{~d}$ ) and wild-type (Fig. 8a,c) embryos. In the $R b-1^{\Delta 20} / R b$ $1^{\Delta 20}$ mutants, however, specific hybridization is conspicuously missing in both trigeminal and dorsal root ganglia (Fig. $8 \mathrm{a}-\mathrm{d}$ ), and this reduced expression persists through E13.5 (Fig. 8e,f) and E 15.5 (not shown). TrkA expression is also significantly reduced in $R b-1^{\Delta 20} / R b-1^{\Delta 20}$ sensory ganglia at E13.5 and E14.5 (Fig. 9b,d) compared with the control embryos (Fig. 9a,c). For unknown reasons, significant TrkA hybridization is observed in the ventral horn of the spinal cord of the mutant (Fig. 9d), but not wildtype (Fig. 9c), embryos. The level of TrkB expression (the receptor for $\mathrm{BDNF} / \mathrm{NT}-4$ ) is also reduced in the mutant although the difference is not as dramatic as with TrkA and $\mathrm{p} 75^{\mathrm{LNGFR}}$ (not shown). RNase protection assays of mRNA from the RB-deficient dorsal root ganglia confirmed the in situ hybridization results for $\operatorname{TrkA}, \operatorname{TrkB}$ and $\mathrm{p} 75^{\text {LNGFR }}$ (not shown). 


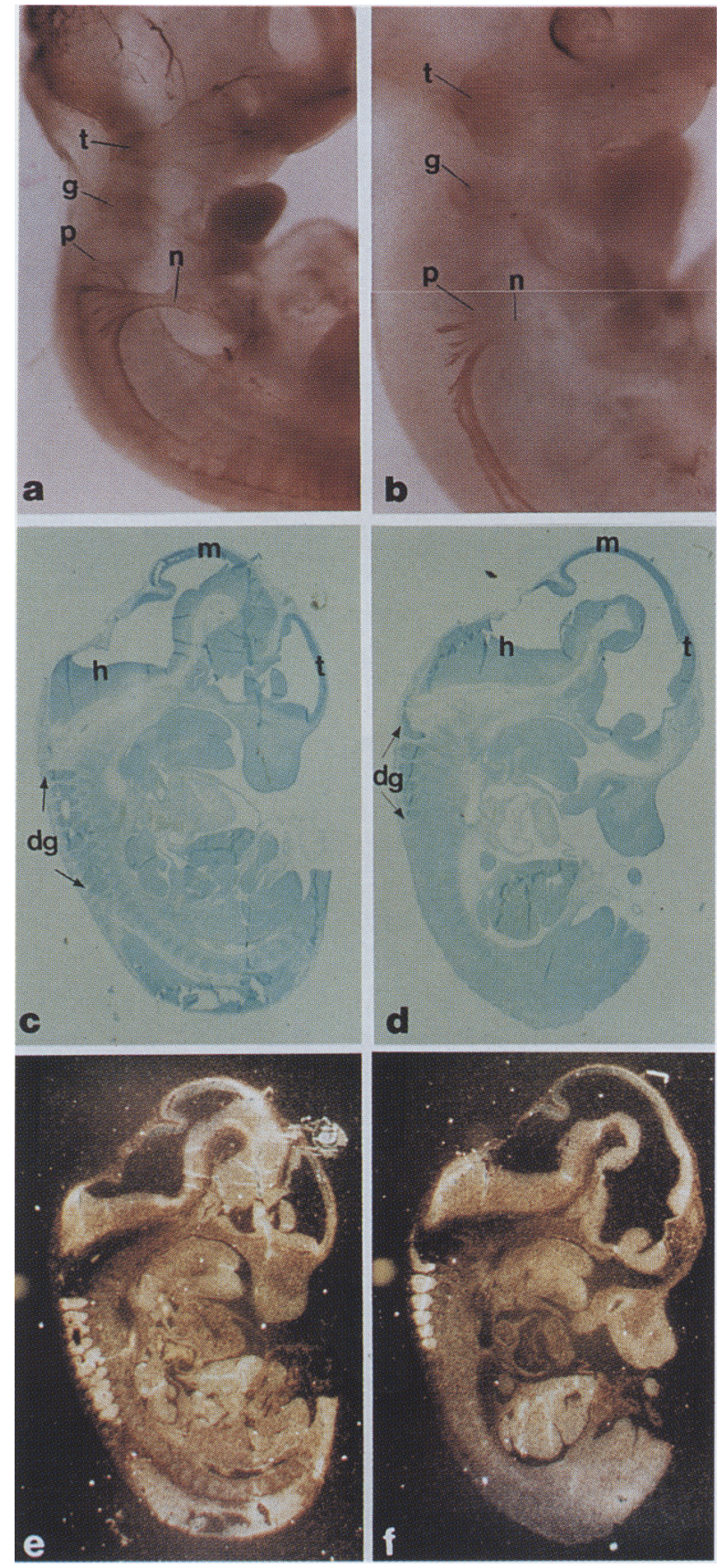

Figure 7. Axon extension from central and peripheral ganglia, and expression of Brn-3.0. $a, b)$ Whole-mount immunohistochemistry of wild-type $(a)$ and mutant, $R b-1^{\Delta 20} / R b-1^{\Delta 20}$ embryo (b), using mAb $2 \mathrm{H} 3$ against the neurofilament $155-\mathrm{kD}$ subunit. Photographs of the mutant embryo are made at two different focal planes. (dg) dorsal root ganglia ${ }_{j}(\mathrm{~h})$ hindbrain $;(\mathrm{m})$ midbrain; $(\mathbf{t})$ telencephalon. $(c, f)$ Expression of Brn-3.0 in $R b-1^{\Delta 20}$, $R b-1^{\Delta 20}$ and control embryos. Bright-field $(c, d)$ and dark-field $(e, f)$ photographs of sagittal sections from E12.5 embryos showing in situ hybridization with Brn-3.0 probe. $(c, e)$ Wild-type embryos; $\{d, f\} R b-1^{\Delta 20} / R b-1^{\Delta 20}$ embryos. (g) Geniculate and acustico-facialis ganglia; $(n)$ nodose ganglia; $(\mathrm{p})$ petrose ganglia; $(\mathrm{t})$ trigeminal ganglia.
Survival and neurite formation of $\mathrm{Rb}-1^{\Delta 20} / \mathrm{Rb}-1^{\Delta 20}$ neuronal cells in vitro

Normal development of a neuron depends on the proper expression of endogenous genes as well as the proper response to exogenous environmental factors. Using sensory ganglia as a model system, we addressed the question of whether death of the ganglionic neurons is a function of their $R b-1^{\Delta 20} / R b-1^{\Delta 20}$ genotype or occurs instead as an indirect consequence of the failing microenvironment in advanced stage mutant embryos. Dissociated single-cell neuronal cultures were established as described in Materials and methods. Trigeminal ganglia cells, harvested at E11.5, survived well in culture for 24 $\mathrm{hr}$ in the presence of NGF. When harvested at E12.5 and afterwards, however, the trigeminal neurons showed much poorer survival (Fig. 10a) and a striking reduction in neurite formation (Fig. 10b). A similar picture was obtained with dorsal root ganglia cells. If E12.5 dorsal root ganglia cells were used as the source of the cell suspension, the neurons survived well for $24 \mathrm{hr}$ (Fig. $10 \mathrm{c}$ ), and their ability to grow neurites was indistinguishable from controls (Fig. 10d). However, if the cells were harvested 1 day later (E13.5), survival was reduced by $30 \%$ and the ability of the surviving cells to grow neurites was decreased by $70 \%$. These results suggest two conclusions. First, until E12.5, the differentiation program of these ganglionic neurons is unaffected by the $R b-1^{\Delta 20} / R b-1^{\Delta 20}$ mutation; this includes the ability of the neurons to extend axons. Second, after E13.5, not even the supportive environment of an NGF-supplemented culture can rescue the neurons or stimulate their maturation (neurite outgrowth). Thus, whereas early differentiation events seem to be unaffected, later events are either retarded or blocked.

\section{Discussion}

The $R b-1$ gene is usually ascribed a role in cell cycle regulation. Specifically, hypophosphorylated RB negatively regulates cell growth by blocking the cell cycle late in $G_{1}$ (for review, see Riley et al. 1994). Our analysis of mouse embryos lacking an intact copy of the $R b-1$ gene further substantiates this function of the protein. Yet, consideration of the entire syndrome of $R b-1^{\Delta 20} / \mathrm{Rb}$ $1^{\Delta 20}$ mice suggests that RB may serve additional functions in the developing nervous system beyond its role in cell cycle arrest.

\section{$R B$ in cell cycle progression and cell cycle exit}

The data described above support the conclusion that RB plays a major role in establishing the postmitotic state of many neuronal cells. BrdU labeling of $R b-1^{\Delta 20} / R b-1^{\Delta 20}$ mutants shows that RB-deficient cells continue to enter $S$ phase even if they are positioned outside of the ventricular zone. Whereas theoretically this could be attributable to premature migration of proliferative RB-deficient cells prior to their normal birthdays, we find this unlikely for three reasons. First, expression of other ner- 

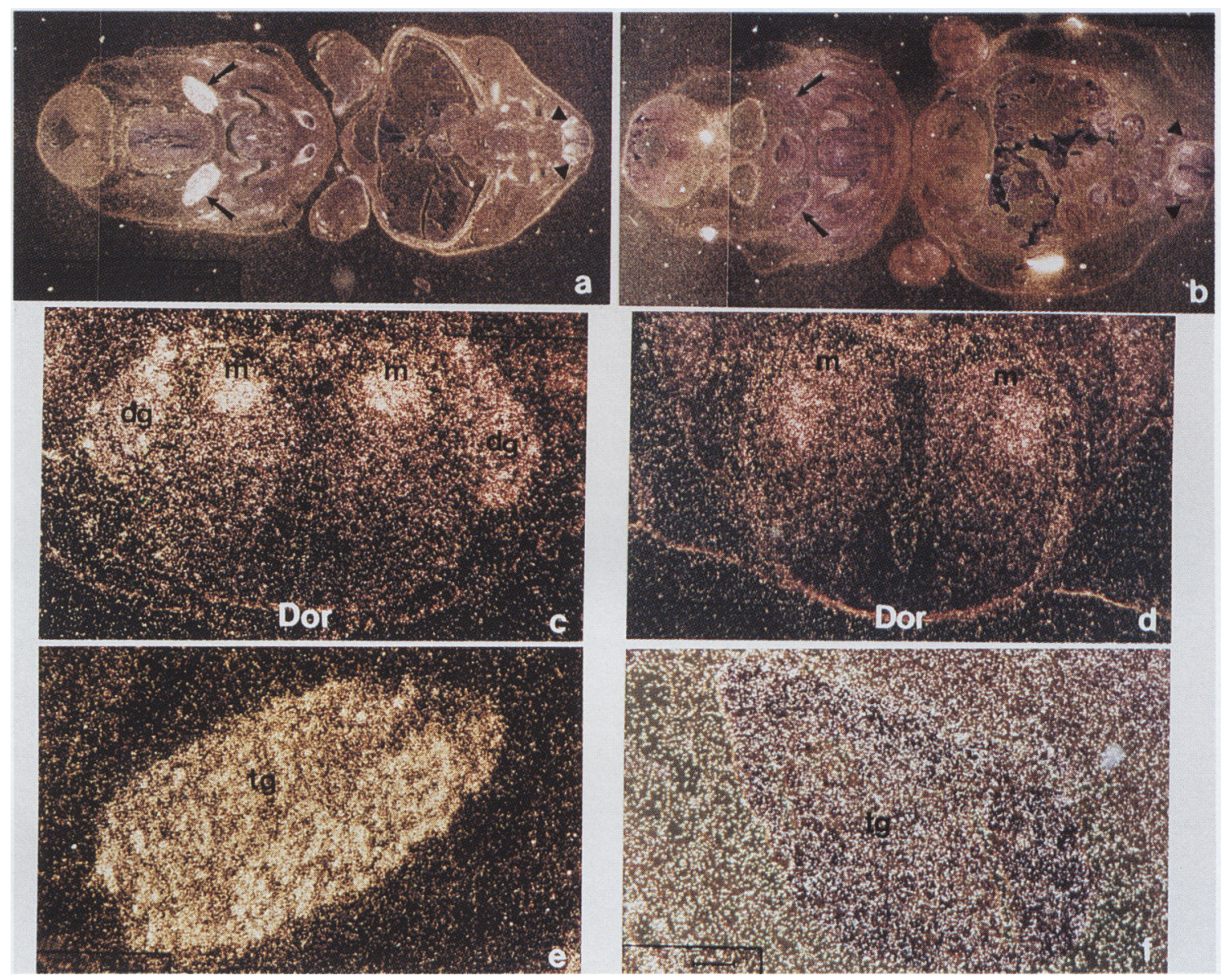

Figure 8. Lack of $\mathrm{p} 75^{\mathrm{LNGFR}}$ expression in sensory ganglia of $R b-1^{\Delta 20} / R b-1^{\Delta 20}$ embryos. In situ hybridization of $\mathrm{p} 75^{\mathrm{LNGFR}}$ in coronal sections of wild-type $(a, c, e)$ and mutant $(b, d, f)$ embryos taken from comparable axial levels. Arrows indicate trigeminal ganglia and arrowheads point to dorsal root ganglia. (dg) Dorsal root ganglia; $(\mathrm{m})$ motor horn; $(\mathrm{tg})$ trigeminal ganglia; (Dor) dorsal side.

vous system genes such as the neuronal adhesion molecule (N-CAM) and the POU family gene (Brn-3.0) appears to be normal in the mutant. Second, the number of proliferating neuroblasts (as revealed by BrdU labeling) is comparable in the ventricular zones of mutant and wildtype embryos. If there were premature emigration of proliferating neuroblasts in the mutant, this could deplete the precursor population. Third, at the stage when most spinal neurogenesis ceases in wild-type embryos, cell proliferation continues in mutant embryos not only in the intermediate zone but also in the ventricular zone (Fig. 3, cf. e and f). These observations argue strongly against the premature emmigration of neuroblasts in the mutant. Taken together, our results suggest that in the absence of functional RB protein, cells in both the CNS and PNS continue to enter S phase temporally and spatially where they should not. Therefore, the demonstrated role of RB in cell cycle arrest in vitro also appears to apply in vivo.

Although the mechanisms of cell cycle regulation are similar in various organisms, the effect of RB deficiency during normal mammalian embryogenesis appears to be unique to the nervous and hematopoietic systems. It is possible that defects in other tissues would become evident if the embryos were able to survive longer. However, no obvious abnormalities have been found in organs whose development precedes the nervous system. For example, the complex morphogenetic events that form the limbs and sculpt the digits on the paws are not disturbed in the mutants. Thus, it is plausible that RB protein is uniquely important to cell cycle regulation in the nervous system.

\section{$R B$ and neuronal differentiation}

It has been demonstrated that elevated levels of RB protein corresponds to neuroectoderm but not endoderm differentiation in embryonic carcinoma cells (Slack et al. 1993). Similarly, $R b-1^{\Delta 20} / R b-1^{\Delta 20}$ embryos demonstrate the specific role of $\mathrm{RB}$ in neuronal differentiation. Based on morphological, biochemical, and developmental genetic criteria, the maturation of several neuronal cell types is either deficient or blocked. We can use the trigeminal ganglia of the PNS as an example. These ganglia 
Figure 9. Lack of TrkA expression in sensory ganglia of $R b-1^{\Delta 20} / R b-1^{\Delta 20}$ embryos. In situ hybridization of trkA in the corresponding coronal sections of wild-type $(a, c)$, and mutant $(b, d)$ embryos. Abbreviations as in Fig. 8.
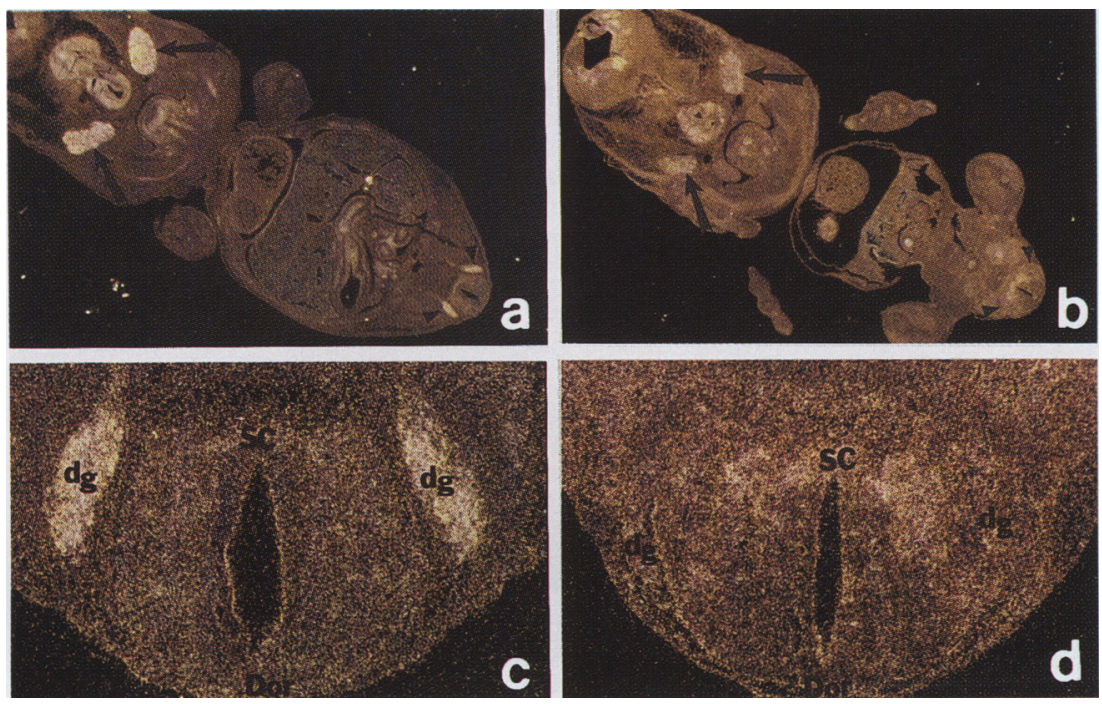

are some of the first neuronal structures to differentiate in the vertebrate nervous system. The neurons send out axons that arrive in their peripheral target fields between E9.5 and E13 (Davies and Lumsden 1984). Two waves of neurogenesis have been described, one before E9 and one between E10 and E12. At the end of the second wave, the ganglion has attained its maximum cell number of $\sim 40,000$. This is followed by a period of naturally occurring cell death during which the number of trigeminal neurons is reduced by approximately one-half (Davies and Lumsden 1984). Cells in RB-deficient embryos appear to successfully complete much of this differentiation program. Ganglion cells are formed and migrate properly to form a normal sized ganglion. Monoclonal antibodies reveal the expected presence of both central and peripheral nerve branches, and (if harvested before E11.5) neurons in single cell cultures are able to survive and extend neurites. At about this stage, however, development in the mutant appears to deteriorate. Cytological maturation is blocked; the cells remain small and the Nissl substance remains rudimentary in the mutant. In addition, several neuronal markers such as BII-tubulin are poorly expressed. N-CAM and Brn-3.0 expression is not altered significantly, and so the lack of differentiation may reflect the aberrant expression of a particular subset of genes.

\section{Expression of neurotrophins and their receptors in $R B$-deficient embryos}

The altered expression patterns of the neurotrophin receptors may provide a partial explanation for the RB mutant phenotypes. The neurotrophins are a family of closely related proteins that play important roles in the development and maintenance of the nervous system. There are characteristic distributions of neurotrophins and their receptors, and the interactions among them appear to be involved in proliferation /Cattaneo and
McKay 1990; Klein et al. 1991a,b), neuronal maturation (Wyatt et al. 1990; Wright et al. 1992; Ip et al. 1993), and maintaining neuronal survival (Barde 1989). These are precisely the phenotypes that are deficient in the $R b$ $1^{\Delta 20} / \mathrm{Rb}-1^{\Delta 20}$ cells.

NGF, the first neurotrophin to be discovered, has been shown to be vital for growth, differentiation, and survival of sympathetic and neural crest-derived sensory neurons (Levi-Montalcini 1987). The activities of neurotrophins are mediated by cell-surface receptors (Chao 1992; Meakin and Shooter 1992; Barbacid 1993). The TrkA gene product is the high-affinity receptor for NGF (Kaplan et al. 1991; Klein et al. 1991a) and TrkB receptor for BDNF and NT-4/5 (Klein et al. 199lb). Function of the low-affinity NGF receptor, $\mathrm{p} 75^{\mathrm{LNGFR}}$, and its role in transduction of the neurotrophin-mediated signal cascade is less clear (Johnson et al. 1986; Radeke et al. 1987). Despite its name, its binding properties make it a poor discriminator among the neurotrophins, and, in contrast to other neurotrophin receptors, it contains no cytoplasmic tyrosine-kinase domain. Nonetheless, in p $75^{\text {LNGFR }}$ null mice, there are deficiencies in sensory responses (K.F. Lee et al. 1992). Optimal growth of $p 75^{\text {LNGFR }}$-deficient neurons requires a higher concentration of NGF (Davis et al. 1993; Lee et al. 1994).

The expression patterns of the neurotrophins themselves are not significantly altered in the $R b-1^{\Delta 20} / \mathrm{Rb}$ $1^{\Delta 20}$ mutant. In contrast, there is a significant reduction in the expression of $\mathrm{p} 75^{\mathrm{LNGFR}}$, the low-affinity NGF receptor, and in TrkA, the high-affinity NGF receptor. The tissue culture data complement this picture. At E12.5 there is no difference in survival and neurite formation between mutant and wild-type dorsal root ganglion cells in vitro. At E13.5, when the dependency of sensory neurons on NGF becomes apparent, there is an $\sim 30 \%$ reduction in survival and $70 \%$ reduction in neurite formation in cultured mutant dorsal root ganglia cells. Likewise, the survival of cultured trigeminal neurons and 
a

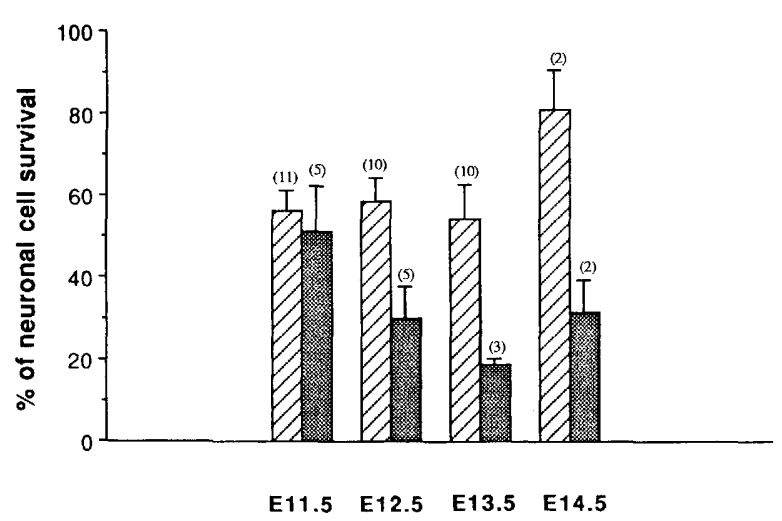

C

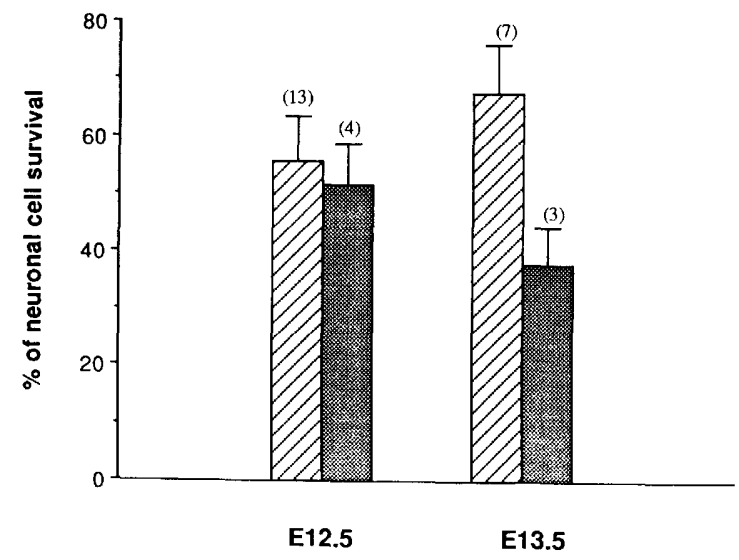

b

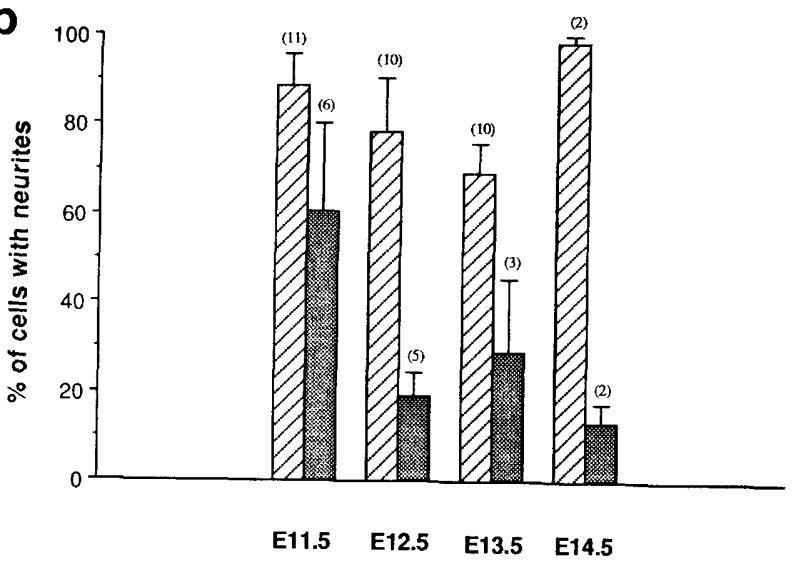

d

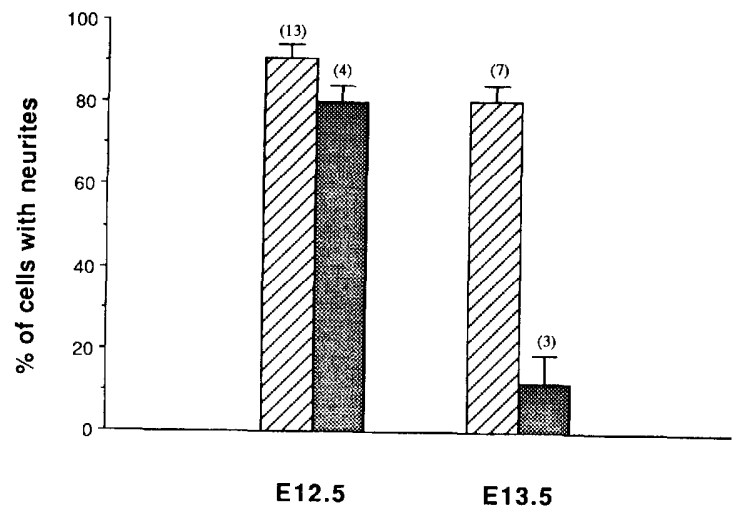

Figure 10. Survival and differentiation of trigeminal and dorsal root ganglia neuronal cells from wild-type and $R b-1^{\Delta 20} / R b-1^{\Delta 20}$ embryos in the presence of NGF. Charts are shown of surviving wild-type neurons (hatched bars) and neurons from RB-deficient embryos (stippled bars) after $24 \mathrm{hr}$ incubation with NGF $(50 \mathrm{ng} / \mathrm{ml})$. The results of typical experiments set up from E11.5-E14.5 trigeminal ganglia are shown. (a) Survival of trigeminal neurons; $(b)$ neurite extension of trigeminal neurons. Similarly, dorsal root ganglion cells from E12.5 and E13.5 embryos were compared. (c) Survival of dorsal root ganglia cells; (d) neurite extension of dorsal root ganglia cells. The mean and standard error of the neuron survival counts and differentiating neurons in duplicate counts are represented.

their ability to grow neurites is lost at about the same ages as trigeminal neurons in vivo become sensitive to neurotrophins. Given these data, its seems possible that the lack of differentiation and the elevated neuronal cell death seen in sensory ganglia of RB-deficient embryos is at least partially, if not wholly, explained by the lack of TrkA and $p 75^{\text {LNGFR }}$ proteins. If this is true, then the RB protein might be important in the establishment of the complete neurotrophin-mediated signal transduction pathway.

\section{$R B$ and cell survival during nervous system development}

That RB should have a role in cell survival is a curious discovery. Cell death is common during CNS development. Approximately half of all neurons generated dur- ing development of the mammalian nervous system die (Cowan et al. 1984; for review, see Oppenheim 1991). Recently, several examples of programmed cell death have been hypothesized to result from loss of cell cycle control (Freeman et al. 1994; Meikrantz et al. 1994), and transgenic mouse experiments in which SV40 T-antigen is ectopically expressed in mature neurons of the CNS directly implicate RB in this process (al-Ubaidi et al. 1992; Feddersen et al. 1992). In the absence of RB, control of expression of a series of genes associated with the cell cycle and positively regulated by the E2F transcriptional factor would be lost; dihydrofolate reductase, thymidine kinase, thymidine synthesis, and others should be activated (Nevin 1992). Our pulse-labeling experiments demonstrate that $R b-1^{\Delta 20} / R b-1^{\Delta 20}$ cells became apoptotic shortly after they enter $S$ phase. It is conceivable that in the absence of RB protein, early events for S-phase entry are initiated and an "alternate effector 
pathway" (Heintz 1993) or conflicting signals in the RBdeficient cells may then lead to cell death.

The findings presented here expand the picture of the function of RB in the developing organism. Our data support the conclusion that the $\mathrm{RB}$ gene product is a key player in the regulation of the cell cycle in the embryonic nervous system. The results illustrate clearly, however, that the loss of $\mathrm{RB}$, in and of itself, does not lead to continuously uncontrolled cell division in any tissue. Development of various nervous structures in the mutant proceeds normally to a critical period of embryogenesis, after which further morphological development is blocked and cell death ensues. Preferential reduction in the expression of several neurotrophin receptor genes in the mutant may explain all or part of the phenotype in the peripheral nervous system. Taken together, our data support the hypothesis that RB plays multiple roles in neuronal development. It appears to be essential for the proper biochemical and morphological development of the young neurons as well as for ensuring their permanent exit from the cell cycle.

\section{Materials and methods}

\section{Animals}

Embryonic stem cells used in the targeting of $R b-1$ gene were derived from an agouti $129 / \mathrm{SvEv}$ mouse (E.Y.-H.P. Lee et al. 1992). Outbred progeny from crosses with C57BL/6 were used for studies described here. All embryos were acquired from the mating of heterozygous $R b-1^{\Delta 20} /+$ parents. Genetically wildtype or heterozygous mice were used interchangeably because our studies reveal no obvious phenotypic difference in their development.

\section{Western blotting analysis}

Timed pregnancies of wild-type mice were established. At each indicated time point, pregnant dams were sacrificed, the fetuses were removed from their amniotic sacs, and the embryonic head or brains were dissected and frozen in liquid nitrogen. Frozen tissues were homogenized in lysis buffer containing $50 \mathrm{mM}$ Tris- $\mathrm{HCl}(\mathrm{pH} 8.0), 120 \mathrm{~mm} \mathrm{NaCl}, 0.5 \% \mathrm{NP}-40,200 \mathrm{U} / \mathrm{ml} 1$ of aprotinin, $50 \mu \mathrm{g} / \mathrm{ml}$ of leupeptin, and $1 \mathrm{mM}$ phenylmethylsufonyl fluoride. Monoclonal antibody 3C8 (Canji, La Jolla) and mAb 245 were used in Western blotting as described previously (Lee et al. 1992). RbAp48 is a cellular protein that associates with RB (Qian et al. 1993), and G $\beta$-like antibody recognizes a 26-kD cellular G $\beta$-like protein (Shan et al. 1992).

\section{FACS analysis}

Hindbrain and cervical spinal cord were removed from E13.5 embryos. Tissues were suspended, triturated in PBS, and filtered through a $53-\mu \mathrm{m}$ nylon mesh. The $200 \mathrm{~g}$ centrifuged cell pellet was fixed in cold $70 \%$ ethanol at $4^{\circ} \mathrm{C}$ for $40 \mathrm{~min}$. The cells were then centrifuged, washed with PBS, treated with RNase for 5 min, followed by addition of propidium iodide according to Nicoletti et al. (1991). The propidium iodide fluorescence of individual nuclei was measured using a FACScan flow cytometer (Becton and Dickinson, Mountain View, CA).

\section{BrdU labeling and immunohistochemistry}

Timed pregnant mice at $10.5,12.5,13.5$, and 14.5 days of gestation were injected intraperitoneally with BrdU (Sigma) at a dose of $100 \mathrm{mg} / \mathrm{kg}$ body weight as described (Miller and Nowakowsi 1988). At different time intervals (1, 2, 3, 5, 12, 24, and 48 $\mathrm{hr}$ ) after injection, pregnant mice were sacrificed and their embryos immediately fixed in Bouin's solution for $24 \mathrm{hr}$ followed by dehydration and embedding in paraffin. Coronal sections of 4-6 $\mu \mathrm{m}$ were prepared. After deparaffinization and rehydration, sections were treated with $200 \mathrm{ml}$ of TBS containing $0.1 \%$ sodium azide and $0.1 \% \mathrm{H}_{2} \mathrm{O}_{2}$ for $30 \mathrm{~min}$, washed in TBS, and incubated with anti-BrdU antibody $\{1: 50$, Becton and Dickinson, $\mathrm{CA}$ ) overnight at $4^{\circ} \mathrm{C}$. An $\mathrm{ABC}$ staining procedure $(1: 100$, $A B C$ kit, Vector) was performed, as per the manufacturer's instructions, using a biotinylated secondary antibody $(1: 100)$. Finally, sections were counterstained with hematoxylin, dehydrated, cleared, and mounted for light microscopic analysis.

\section{Identification of apoptotic cells in situ}

The TUNEL technique essentially follows the protocol of Gavrieli et al. (1992). Tissue samples were fixed in $4 \%$ paraformaldehyde solution and embedded in paraplast, and sections were prepared for labeling.

\section{Genomic DNA extraction and $3^{\prime}$ end-labeling of DNA}

Dorsal root and trigeminal ganglia were dissected from E13.5 mouse embryos, the constituent cells were lysed in lysis buffer $(10 \mathrm{~mm}$ Tris at $\mathrm{pH} 8.0,1 \mathrm{~mm}$ EDTA, $0.2 \%$ SDS, $0.1 \mathrm{M} \mathrm{NaCl}, 0.5$ $\mathrm{mg} / \mathrm{ml}$ of proteinase $\mathrm{K}$ ), and genomic DNA was extracted. For $3^{\prime}$ end-labeling, $500 \mathrm{ng}$ of DNA was incubated with $20 \mu \mathrm{Ci}$ of $\left[\alpha^{-32} \mathrm{P}\right] \mathrm{ddATP}$ (3000 Ci/mmole; Amersham), and 24 units of terminal deoxynucleotidyl transferase $(24 \mathrm{U} / \mu \mathrm{l}$, IBI) in a total volume of $42 \mu \mathrm{l}$. The reaction was carried out at $37^{\circ} \mathrm{C}$ for $60 \mathrm{~min}$ and terminated by the addition of $5 \mu$ l of $0.25 \mathrm{M}$ EDTA (Tilly and Hsueh 1993). Unincorporated radionucleotide was removed by ethanol precipitation. One-fifth of the labeled DNA sample was separated on a $1.8 \%$ agarose gel followed by transfer to a nylon membrane. An autoradiograph of the transfer was obtained by exposure to a Kodax X-ray film at $-70^{\circ} \mathrm{C}$ for $3 \mathrm{hr}$.

\section{In situ hybridization}

Embryos at various stages were placed in ice-cold, freshly prepared $4 \%$ paraformaldehyde in PBS overnight. Paraffin sections were prepared following successive dehydration and embedding of embryos in paraffin. In situ hybridization was performed according to Cox et al. (1984). For TrkA, TrkB, TrkC, and N-CAM, single-stranded anti-sense RNA probes were generated using $\left[{ }^{33} \mathrm{P}\right]$ UTP and T7 or SP6 RNA polymerase following the manufacturer's instructions (Promega). About $5 \times 10^{7} \mathrm{cpm}$ of $\left[{ }^{33} \mathrm{P}\right]$ UTP-labeled RNA probes of $\sim 300$ bp length were used for hybridization. Sections were covered with NB-2 photo emulsion $(1: 1$, Kodak $)$ and exposed for $3-6$ weeks at $4^{\circ} \mathrm{C}$. Sections were developed, fixed, and counterstained with toluidene blue (Cox et al. 1984). For p75 ${ }^{\text {LNGFR }}$, NGF, BDNF, NT-3, and neuronal $\beta I I$ tubulin, 50-mer oligonucleotides probes were labeled at their $3^{\prime}$ end with $\left[\alpha^{-33} \mathrm{P}\right] \mathrm{dATP}$ and TdT to a specific activity of $\sim 10^{9}$ $\mathrm{cpm} / \mu \mathrm{g}$ and purified through a NENsorb column (Du Pont). The following anti-sense oligonucleotides, derived from the species and corresponding to nucleotide positions (indicated in parenthesis), were used. Rat p75 ${ }^{\text {LNGFR }}$ (867-916; Radeke et al. 1987): 5'-ACAAGGCCCACGACCACAGCAGCCAAGATGGAGCAATAGACAGGAATGAG-3'. Mouse neuronal $\beta I I$ tubulin (3'-untranslated region; Lewis et al. 1985): 5'-TGGAGGACAACAGAAGTTCACTAAGGGTGCACACTGTATCTGAGAAGTTC-3'. Mouse Brn-3.0 (1207-1257; Gerrero et al. 1993): 
5'-CTTCTTCTCGCCGCCGTTGAAGAGCTCCGGCTTGTTCATTTTCTCACGTTG-3'.

For oligonucleotide probes, hybridization was carried out at $42^{\circ} \mathrm{C}$ overnight, followed by washing in $0.1 \times \mathrm{SSC}$ at $40^{\circ} \mathrm{C}$.

\section{Whole-mount immunostaining of mouse embryos}

Procedures essentially followed Mark et al. (1993). 2H3 is a monoclonal antibody against the $155-\mathrm{kD}$ neurofilament protein and was obtained from the Developmental Studies, Hybridoma Bank maintained by the Department of Pharmacology and Molecular Sciences, Johns Hopkins University School of Medicine (Baltimore, MD) and the Department of Biological Sciences, University of Iowa (Iowa City, IA), under contract N01-HD-23144 from the National Institute of Child Health and Human Development.

\section{Neuronal cell culture}

Dorsal root and trigeminal ganglia were dissected from E11.5, E12.5, E13.5, and E14.5 mouse embryos. Ganglia were treated with $0.25 \%$ trypsin-EDTA for $\sim 10 \mathrm{~min}$, tissues were then triturated and washed. Cells were plated onto laminin $(15 \mu \mathrm{g} / \mu \mathrm{l}$; GIBCO)-coated 24-well cell culture clusters (Costar) at $4 \times 10^{4}$ cells/well for dorsal root ganglia and $2 \times 10^{4}$ cells $/$ well for trigeminal ganglia in OPTI-MEM reduced-serum medium (GIBCO) supplemented with $\mathrm{N}-2$ (GIBCO), NGF $(50 \mathrm{ng} / \mathrm{ml}$; UBI), $0.6 \%$ glucose, ampicillin, and streptomycin. Neuron survival and neurite formation were compared 6,24 , and $72 \mathrm{hr}$ after plating using a phase contrast microscope.

\section{Acknowledgments}

We thank Dr. M. Barbacid for the mouse neurotrophin receptor plasmids, Dr. Marie-Josee Santoni for N-CAM plasmid, Ms. Nancy Ransom for advice on TUNEL staining, Dr. K.-F. Lee for valuable discussion, and Dr. P. Zeng for contributions in the early phase of the studies. This work was supported by National Institutes of Health grants to E.Y.-H.P. L. (HD30625) and to K.H. (NS18381).

The publication costs of this article were defrayed in part by payment of page charges. This article must therefore be hereby marked "advertisement" in accordance with 18 USC section 1734 solely to indicate this fact.

\section{References}

al-Ubaidi, M.R., J.G. Hollyfield, P.A. Overbeek, and W. Baehr. 1992. Photoreceptor degeneration induced by the expression of simian virus 40 large tumor antigen in the retina of transgenic mice. Proc. Natl. Acad. Sci. 89: 1194-1198.

Barbacid, M. 1993. Nerve growth factor: A tale of two receptors. Oncogene 8: 2033-2042.

Barde, Y.-A. 1989. Trophic factors and neuronal survival. Neuron 2: 1525-1534.

Bernards, R., G.M. Schackleford, M.R. Gerber, J.M. Horowitz, S.H. Friend, M. Schartl, E. Bogenmann, J.M. Rapaport, T. McGee, T.P. Dryja, and R.A. Weinberg. 1989. Structure and expression of the murine retinoblastoma gene and characterization of its encoded protein. Proc. Natl. Acad. Sci. 86: 6474-6478.

Buchkovich, K., L.A. Duffy, and E. Harlow. 1989. The retinoblastoma protein is phosphorylated during specific phases of the cell cycle. Cell 58: 1097-1105.

Buolfone, A., L. Puelles, M.H. Porteus, M.A. Frohman, G.R.
Martin, and J.L.R. Rubenstein. 1993. Spatially restricted expression of Dlx-1, Dlx-2 (Tes-1), Gbx-2 and Wnt-3 in the embryonic day 12.5 mouse forebrain defines potential transverse and longitudinal segmental boundaries. I. Neurosci. 13: $3155-3172$.

Cattaneo, E. and R. McKay. 1990. Proliferation and differentiation of neuronal stem cells regulated by nerve growth factor. Nature 347: 762-765.

Chao, M. 1992. Neurotrophin receptors: A window into neuronal differentiation. Neuron 9: 583-593.

Chen, P.-L., P. Scully, J.-Y. Shew, J.Y.-J. Wang, and W.-H. Lee. 1989. Phosphorylation of the retinoblastoma gene product is modulated during the cell cycle and cellular differentiation. Cell 58: 1193-1198.

Clarke, A.R., E.R. Maandag, M. van Roon, N.M.T. van der Lugt, M. van der Valk, M.L. Hooper, A. Berns, and H.t. Riele. 1992. Requirement for a functional Rb-1 gene in murine development. Nature 359: 328-330.

Cowan, W.M., J.W. Fawett, D.M. O'Leary, and B.B. Stanfield. 1984. Regressive events in neurogenesis. Science 225: 12581265.

Cox, K.H., D.V. DeLeon, L.M. Angerer, and R.C. Angerer. 1984. Detection of mRNAs in sea urchin embryos by in situ hybridization using asymmetric RNA probes. Dev. Biol. 101: 485-502.

Davies, A.M. and A. Lumsden. 1984. Relation of target encounter and neuronal death to nerve growth factor responsiveness in the developing mouse trigeminal ganglion. J. Comp. Neurol. 223: 124-137.

Davis, A.M., K.-F. Lee, and R. Jaenisch. 1993. p75-deficient trigeminal sensory neurons have an altered response to NGF but not to other neurotrophins. Neuron 11: 565-574.

DeCaprio, J.A., J.W. Ludlow, D. Lynch, Y. Furukawa, J. Griffin, H. Pawnica-Worms, C.-M. Huang, and D.M. Livingston. 1989. The product of the retinoblastoma susceptibility gene has properties of a cell cycle regulatory element. Cell 58: 1085-1095.

DeCaprio, J.A., Y. Furukawa, F. Ajechenbaum, J.D. Griffin, and D. Livingston. 1992. The retinoblastoma-susceptability gene product becomes phosphorylated in multiple stages during cell cycle entry and progression. Proc. Natl. Acad. Sci. 89: 1795-1798.

Feddersen, R.M., R. Ehlenfeldt, W.S. Unis, H.B. Clark, and H.T. Orr. 1992. Disrupted cerebellar cortical development and progressive degeneration of Purkinje cells in SV40 T antigen transgenic mice. Neuron 9: 955-966.

Freeman, R.S., S. Estus, and E.M. Johnson Jr. 1994. Analysis of cell cycle-related gene expression in postmitotic neurons: Selective induction of cyclin D1 during programmed cell death. Neuron 12: 343-355.

Gavrieli, Y., Y. Sherman, and S.A. Ben-Sasson. 1992. Identification of programmed cell death in situ via specific labeling of nuclear DNA fragmentation. J. Cell Biol. 119: 493-501.

Gerrero, M.R., R.J. McEvilly, E. Turner, C.R. Lin, S. O'Connell, K.J. Jenne, M.V. Hobbs, and M.G. Rosenfeld. 1993. Brn-3.0: A POU-domain protein expressed in the sensory, immune, and endocrine systems that functions on elements distinct from known octamer motifs. Proc. Natl. Acad. Sci. 90: 1084110845.

Goodrich, D.W., N.P. Wang, Y. Qian, E.Y.-H.P. Lee, and W.-H. Lee. 1991. The retinoblastoma gene product regulates progression through G1 phase of the cell cycle. Cell 67: 293302.

He, X. and M.G. Rosenfeld. 1991. Mechanisms of complex transcriptional regulation: Implications for brain development Neuron 7: 183-196. 
Heintz, N. 1993. Cell death and the cell cycle: a relationship between transformation and neurodegeneration? Trends Biochem. Sci. 18: 157-159.

Helin, K., J.A. Lees, M. Vidal, N. Dyson, E. Harlow, and A. Fattaey. 1992. A cDNA encoding a pRB-binding protein with properties of the transcription factor E2F. Cell 70: 337-350.

Hu, N., A. Gutsmann, D.C. Herbert, A Bradley, W.-H. Lee, and E.H.-H.P. Lee. 1994. Heterozygous rb-1/+ mice are predisposed to tumors of the pituitary gland with a nearly complete penetrance. Oncogene 9: 1021-1027.

Hu, Q., J.A. Lees, K.J. Buchkovich, and E. Harlow. 1992. The retinoblastoma protein physically associates with the human cdc2 kinase. Mol. Cell. Biol. 12: 971-980.

Huang, H.-J.S., J.-K. Yee, J.-Y. Shew, P.-L. Chen, R. Bookstein, T. Friedmann, E.Y.-H.P. Lee, and W.-H. Lee. 1988. Suppression of the neoplastic phenotype by replacement of the retinoblastoma gene product in human cancer cells. Science 242: $1563-1566$.

Ip, N.Y., T.N. Stitt, P. Tapley, R. Klein, D.J. Glass, J. Fandl, L. Greene, M. Barbacid, and G.D. Yancopoulos. 1993. Similarities and differences in the way neurotrophins interact with the trk receptors in neuronal and nonneuronal cells. Neuron 10: 137-149.

Jacks, T., A. Fazeli, E.M. Schmitt, R.T. Bronson, M.A. Goodell, and R.A. Weinberg. 1992. Effects of an Rb mutation in the mouse. Nature 359: 295-300.

Johnson, D., A. Lanahan, C.R. Buck, A. Sehgal, C. Morgan, E. Mercer, M. Bothwell, and M. Chao. 1986. Expression and structure of the human NGF receptor. Cell 47: 545-554.

Kaelin, W.G., W. Krek, W.R. Sellers, J.A. DeCaprio, F. Ajchenbaum, C.S. Fuchs, T. Chittenden, Y. Li, P.J. Farnham, M.A. Blanar, D.M. Livingston, and E.K. Flemington. 1992. Expression cloning of a cDNA encoding a retinoblastoma-binding protein with E2F-like properties. Cell 70: 351-364.

Kaplan, D.R., B.L. Hempstead, Z.D. Martin, M.V. Chao, and L.F. Parada. 1991. The trk proto-oncogene product: A signal transducing receptor for nerve growth factor. Science 252: 554-558.

Karantza, V., A. Maroo, D. Fay, and J.M. Sedivy. 1993. Overproduction of $\mathrm{Rb}$ protein after the G1/S boundary causes $\mathrm{G} 2$ arrest. Mol. Cell. Biol. 13: 6640-6652.

Klein, R., S.Q. Jing, V. Nanduri, E. O'Rourke, and M. Barbacid. 1991a. The trk proto-oncogene encodes a receptor for nerve growth factor. Cell 65: 189-197.

Klein, R., V. Nanduri, S.A. Jing, F. Lamballe, P. Tapley, S. Bryant, C.C. Cordon-Cardon, K.R. Jones, L.F. Reichardt, and M. Barbacid. 1991b. The trkB tyrosine proteinase is a receptor for brain-derived neurotrophic factor and neurotrophin. Cell 66: 395-403.

Lee, E.Y.-H. P., C.Y. Chang, N. Hu, Y.-C.J. Wang, C.-C. Lai, K. Herrup, W.-H. Lee, and A. Bradley. 1992. Mice deficient for $\mathrm{Rb}$ are nonviable and show defects in neurogenesis and haematopoiesis. Nature 359: 288-294.

Lee, K.F., E. Li, L.J. Huber, S.C. Landis, A.H. Sharpe, M.V. Chao, and R. Jaenisch. 1992. Targeted mutation of the gene encoding the low affinity NGF receptor p75 leads to deficits in the peripheral sensory nervous system. Cell 69: 737-749.

Lee, K.-F., A.M. Davies, and R. Jaenisch. 1994. p75-deficient embryonic dorsal root sensory and neonatal sympathetic neurons display a decreased sensitivity to NGF. Development 120: 1027-1033.

Lee, W.-H., J.-Y. Shew, F. Hong, T. Sery, L.A. Donoso, L.J. Young, R. Bookstein, and E.Y.-H.P. Lee. 1987. The retinoblastoma susceptibility gene product is a nuclear phosphoprotein associated with DNA binding activity. Nature 329: 642-645.
Levi-Montalcini, R. 1987. The nerve growth factor: Thirty-five years later. $E M B O$ \%. 6: 1145-1154.

Lewis, S.A., M.G.-S. Lee, and N.J. Cowan. 1985. Five mouse tubulin isotypes and their regulated expression during development. J. Cell Biol. 101: 852-861.

Lin, B.T.-Y., S. Gruenwald, A.O. Morla, W-H. Lee, and J.Y.J. Wang. 1991. Retinoblastoma cancer suppressor gene product is a substrate of the cell cycle regulator cdc2 kinase. $E M B O$ J. 10: 857-864.

Ludlow, J.W., J. Shon, J.M. Pipas, D.M. Livingston, and J.A. DeCaprio. 1990. The retinoblastoma susceptibility gene product undergoes cell cycle-dependent dephosphorylation and binding to and release from SV40 large T. Cell 60: 387-396.

Ludlow, J.W., C.L. Glendening, D.M. Livingston, and J.A. DeCaprio. 1993. Specific enzymatic dephosphorylation of the retinoblastoma protein. Mol. Cell. Biol. 13: 367-372.

Ma, W., T. Behar, D. Maric, I. Maric, and J.L. Barker. 1992. Neuroepithelial cells in the rat spinal cord express glutamate decarboxylase immunoreactivity in vivo and in vitro. I. Comp. Neurol. 325: 257-270.

Mark, M., T. Lufkin, J.-L. Vonesch, E. Ruberte, J.-C. Olivo, P. Dolle, P. Gorry, A. Lumsden, and P. Chambon. 1993. Two rhombomeres are altered in Hoxa-1 mutant mice. Development 119: 319-338.

Meakin, S.O. and E.M. Shooter. 1992. The nerve growth factor family of receptors. Trends Neurosci. 15: 323-331.

Meikrantz, W., S. Gisselbrecht, S.W. Tam, and R. Schlegel. 1994. Activation of cyclin A-dependent protein kinases during apoptosis. Proc. Natl. Acad. Sci. 91: 3754-3758.

Miller, M.W. and R.S. Nowakowski. 1988. Use of bromodeoxyuridine-immunohistochemistry to examine the proliferation, migration and time of origen of cells in the central nervous system. Brain Res. 457: 44-52.

Nevin, J.R. 1992. A link between the Rb tumor suppressor protein and viral oncoproteins. Science 258: 424-429.

Nicoletti, I., G. Migliorati, M.C. Pagliacci, F. Grignani, and C. Riccardi. 1991. A rapid and simple method for measuring thymocyte apoptosis by propidium iodide staining and flow cytometry. I. Immunol. Methods 139: 271-279.

Nowakowski, R.S., S.B. Lewin, and M.W. Miller. 1989. Bromodeoxyuridine immunohistochemical determination of the lengths of the cell cycle and the DNA-synthetic phase for an anatomically defined population. I. Neurocytol. 18: 311318.

Oppenheim, R.W. 1991. Cell death during development of the nervous system. Annu. Rev. Neurosci. 14: 453-501.

Qian, Y.-W., Y.-C.J. Wang, R.E. Hollingsworth, D. Jones, N. Ling, and E.Y.-H.P. Lee. 1993. A retinoblastoma-binding protein related to a negative regulator of Ras in yeast. Nature 364: 648-652.

Qin, X.-Q., T. Chittenden, D.M. Livingston, and W.G. Kaelin. 1992. Identification of a growth suppression domain within the retinoblastoma gene product. Genes \& Dev. 6: 953-964.

Radeke, M.J., T.P. Misko, C. Hsu, L.A. Herzenberg, and E.M. Shooter. 1987. Gene transfer and molecular cloning of the rat nerve growth factor receptor. Nature 325: 593-396.

Riley, D.J., E.Y.-H.P. Lee, and W.-H. Lee. 1994. Retinoblastoma gene: More than a tumor suppressor. Annu. Rev. Cell Biol. (in press).

Rothman, T.P., L.A. Specht, M.D. Gershon, T.H. Joh, G. Teitelman, V.M. Picket, and D.J. Reis. 1980. Catecholamine biosynthetic enzymes are expressed in replicating cells of the peripheral but not central nervous system. Proc. Natl. Acad. Sci. 77: 6221-6225.

Shan, B., X. Zhu, P.-L. Chen, T. Durfee, Y. Yang, D. Sharp, and W.-H. Lee. 1992. Molecular cloning of cellular genes encod- 
ing retinoblastoma-associated proteins: Identification of a gene with properties of the transcription factor E2F. Mol. Cell. Biol. 12: 5620-5631.

Shew, J.-Y., N. Ling, X. Yang, O. Fodstad, and W.-H. Lee. 1989. Antibodies detecting abnormalities of the retinoblastoma susceptibility gene product (ppl10RB) in osteosarcomas and synovial sarcomas. Oncogene Res. 1: 205-214.

Slack, R.S., P.A. Hamel, T.S. Bladon, R.M. Gill, and M.W. McBurney. 1993. Regulated expression of the retinoblastoma gene in differentiating embryonal carcinoma cells. Oncogene 8: 1585-1591.

Szekely, L., W.-Q. Jiang, F. Bulic-Jakus, A. Rosen, N. Ringertz, G. Klein, and K.G. Wiman. 1992. Cell type and differentiation dependent heterogeneity in retinoblastoma protein expression in SCID mouse fetuses. Cell Growth $\Theta$ Differ. 3: 139-156.

Taber-Pierce, E. 1973. Time of origin of neurons in the brain stem of the mouse. Brain Res. 40: 53-66.

Tilly, J.L. and A.J.W. Hsueh. 1993. A microscale autoradiographic method for the qualitative and quantitative analysis of apoptotic DNA fragmentation. J. Cell. Physiol. 154: 519526.

Wright, E.M., K.S. Vogel, and A.M. Davies. 1992. Neurotrophic factors promote the maturation of developing sensory neurons before they become dependent on these factors for survival. Neuron 9: 139-150.

Wyatt, S., E.M. Shooter, and A.M. Davies. 1990. Expression of the NGF receptor gene in sensory neurons and their cutaneous targets prior to and during innervation. Neuron 4: 421427. 


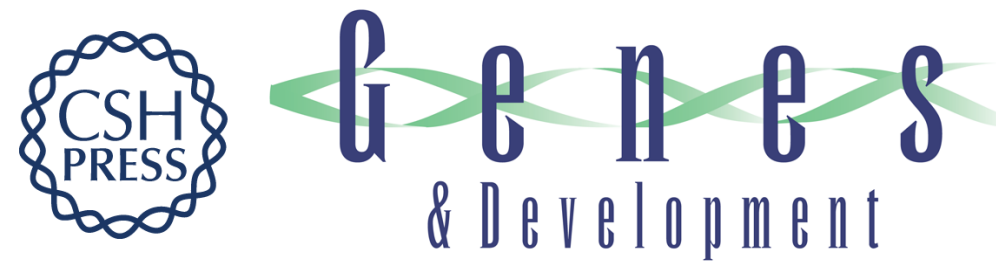

\section{Dual roles of the retinoblastoma protein in cell cycle regulation and neuron differentiation.}

E Y Lee, N Hu, S S Yuan, et al.

Genes Dev. 1994, 8:

Access the most recent version at doi:10.1101/gad.8.17.2008

References This article cites 64 articles, 20 of which can be accessed free at:

http://genesdev.cshlp.org/content/8/17/2008.full.html\#ref-list-1

License

Email Alerting

Service

Receive free email alerts when new articles cite this article - sign up in the box at the top right corner of the article or click here.

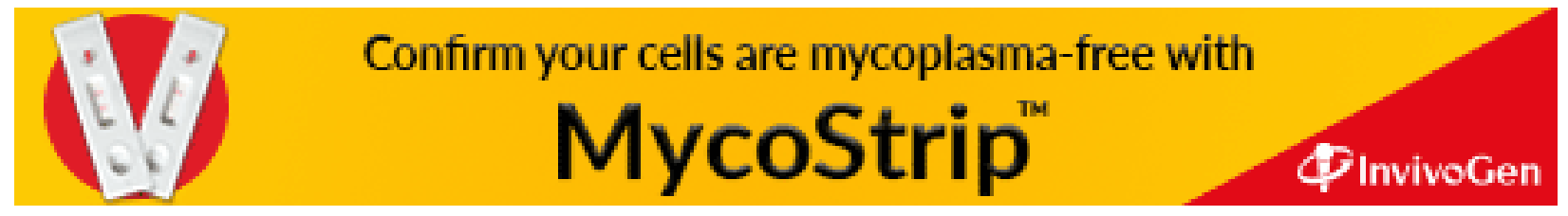

